\title{
The invasive snowflake coral (Carijoa riisei) in the Tropical Eastern Pacific, Colombia
}

\author{
Juan Armando Sánchez ${ }^{1} \&$ Diana Ballesteros ${ }^{1,2}$ \\ 1. Departamento de Ciencias Biológicas-Facultad de Ciencias, Laboratorio de Biología Molecular Marina (BIOMMAR), \\ Universidad de los Andes, Bogotá, Colombia; juansanc@uniandes.edu.co \\ 2. BEM. Instituto de Investigaciones Marinas y Costeras, Invemar, Santa Marta, Colombia; \\ diana.carolinab09@gmail.com
}

Recibido 18-X-2013. Corregido 20-XI-2013. Aceptado 19-XII-2013.

\begin{abstract}
Carijoa riisei (Octocorallia: Cnidaria), a western Atlantic species, has been reported in the Pacific as an invasive species for nearly forty years. $C$. riisei has been recently observed overgrowing native octocorals at several rocky-coral littorals in the Colombian Tropical Eastern Pacific-(TEP). C. riisei has inhabited these reefs for at least 15 years but the aggressive overgrowth on other octocorals have been noted until recently. Here, we surveyed for the first time the distribution and inter-specific aggression by $C$. riisei in both coastal and oceanic areas colonized in the Colombian TEP (Malpelo, Gorgona and Cabo Corrientes), including preliminary multiyear surveys during 2007-2013. We observed community-wide octocoral mortalities (including local extinction of some Muricea spp.) and a steady occurrence of competing and overgrowing Pacifigorgia seafans and Leptogorgia seawhips. In Gorgona Island, at two different sites, over $87 \%$ ( $\mathrm{n}=77$ tagged colonies) of octocorals (Pacifigorgia spp. and Leptogorgia alba) died as a result of C. riisei interaction and/or overgrowth between 2011 and 2013. C. riisei overgrows octocorals with an estimate at linear growth rate of about $1 \mathrm{~cm} \mathrm{~m}^{-1}$. The aggressive overgrowth of this species in TEP deserves more attention and regular monitoring programs. Rev. Biol. Trop. 62 (Suppl. 1): 199-207. Epub 2014 February 01.
\end{abstract}

Key words: Carijoa riisei, octocorals, invasive species, Tropical Eastern Pacific, Gorgona, Malpelo, Cabo Corrientes, Chocó, Colombia.

Carijoa riisei, or snowflake coral, is an octocoral species originally from the Tropical Western Atlantic, where it inhabits both reef environments and new underwater surfaces such as sunken ships and pier pilings (Bayer, 1961; Sánchez, 1994). It was first spotted out of its natural range in Hawaii in 1972 where, in addition, it has been seen overgrowing black corals, threatening an important economic resource in the archipelago (Kahng \& Grigg, 2005; Kahng, 2006). This species is in close symbiosis with the sponge Desmapsamma anchorata that carries potent cytotoxic compounds (Calcinai, Bavestrello \& Cerrano, 2004), that strengthens the stolonal expansion of the $C$. riisei colony providing an additional advantage to compete for substrate and overgrow other octocorals.

C. riisei is a generalist filter-feeder, which is another important characteristic for an alien species to succeed in new habitats. Additional advantageous traits of $C$. riisei include a fast linear branch growth rate that could exceed $1 \mathrm{~cm}$ per week, and rapid sexual maturation, where colony branches as little as $2.5 \mathrm{~cm}$ are already mature (Kahng, Benayahu, Wagner \& Rothe, 2008). Although, C. riisei has few natural predators, such as the aeolid nudibranch Phyllodesmium poindimie, unfortunately there has been no luck applying these species as biocontrols in Hawai'i (Wagner, Kahng \& Toonen, 2009). 
C. riisei has been recently observed overgrowing native octocorals at several rockycoral littorals in the Colombian Tropical Eastern Pacific-TEP (Gutiérrez, 2010; Gútierrez, 2012). Observations by local divers, including Cabo Corrientes, and Gorgona, and Malpelo islands, suggest that $C$. riisei has inhabited these reefs for at least 15 years (Bessudo \& Gomez, pers. comm.). However, the aggressive overgrowth on other octocorals has been noted until recently (A. Gomez, for Cabo Corrientes; personal communication; Fig. 1). In addition, we have observed that sea fans usually overgrown by $C$. riisei are often more susceptible, or likely immune-compromised, to fungal diseases and mortality (Fig. 2). The aim of this study was to assess for the first time the distribution and inter-specific aggression by $C$. riisei in the Colombian TEP, including preliminary multiyear qualitative and quantitative surveys.

\section{MATERIALS AND METHODS}

We spotted the presence of Carijoa riisei in Gorgona Island during August of 2007 and since then we examined the same areas in 2011 and 2013 (Fig. 3B). Samples of C. riisei were examined under the microscope for identification using sclerites (Bayer 1961, Sánchez 1994). In addition, we started surveys on reefs in Malpelo Island $(2009,2011,2013)$ and Cabo Corrientes, Chocó, during 2008-2012 (Fig. 3A and C). Please see Sánchez et al., 2013 (this volume) for a description of the sites in Gorgona Island, Barrero-Canosa, Dueñas \& Sánchez (2013) for Cabo Corrientes and Sánchez, Gómez, Escobar \& Dueñas (2011) for Malpelo Island. Using SCUBA, we qualitatively surveyed most coral reefs and infra-littorals during the first year of observations at the three localities in order to spot the distribution of $C$. riisei. We started regular photographic surveys at least once a year on reefs in Malpelo Island (El Freezer-El Submarino site), Gorgona Island (Montañita 2, El Laberinto and El horno), and Cabo Corrientes (El Cabo, La Roñosa, Pieda Bonita, Parguera 7, Parguera 12 and Rocata) (See details in Fig. 3). At each site we spotted the presence of localized dense stands of $C$. riisei and tagged several gorgonian corals that were directly affected by the invasive species or that were nearby high $C$. riisei cover areas. The octocorals were tagged at the base with cable ties and aluminum labels and/or $30 \mathrm{~cm}$ stainless steel rods cemented to the rock. More frequent surveys were completed every four months in all sites at Cabo Corrientes, including photo surveys of 15 Pacifigorgia irene tagged colonies that were actively overgrown by $C$. riisei from Parguera 7 (5), Roñosa (1) and Piedra Bonita (9). Those colonies were examined along a 20-month period including six images, 3-4 months apart each, for most colonies, starting in July 2010 and ending in April 2012. In order to estimate C. riisei overgrowth rate, we took digital images of these colonies against a flat background and a translucent cover slate, including a $10 \times 10 * \mathrm{~cm}$ grid as distortion and scale reference. Linear growth of the longest $C$. riisei branch was measured following the methods described by Lasker, Boller, Castanaro \& Sanchez (2003), and Cadena \& Sánchez (2010).

\section{RESULTS}

Gorgona Island: Dense C. riisei areas were observed on reefs of Gorgona Island during 2007 at Montañita 2 and Los Farallones sites (Fig. 3B). Marked sites at Montañita 2 ( $15 \mathrm{~m}$ depth, two steel rods $50 \mathrm{~m}$ apart) had significantly lower abundance two years after, but new occurrences of $C$. riisei were observed in mid 2010 in shallower rocky outcrops (Fig. 4). Marked steel rods at Los Farallones, facing a nearly vertical wall of large rock builders, revealed a shift in the $C$. riisei patch towards deeper substrates including whole-octocoral community mortality in the original area during June 2011. This was noted with the disappearance of $C$. riisei (above $12 \mathrm{~m}$ ), the absence of octocorals taller than $4 \mathrm{~cm}$, and numerous remains of gorgonian skeleton. It was noticeable that the aposymbiotic scleractinian coral Tubastraea coccinea was not overgrown or affected by $C$. riisei in any of Gorgona sites. 

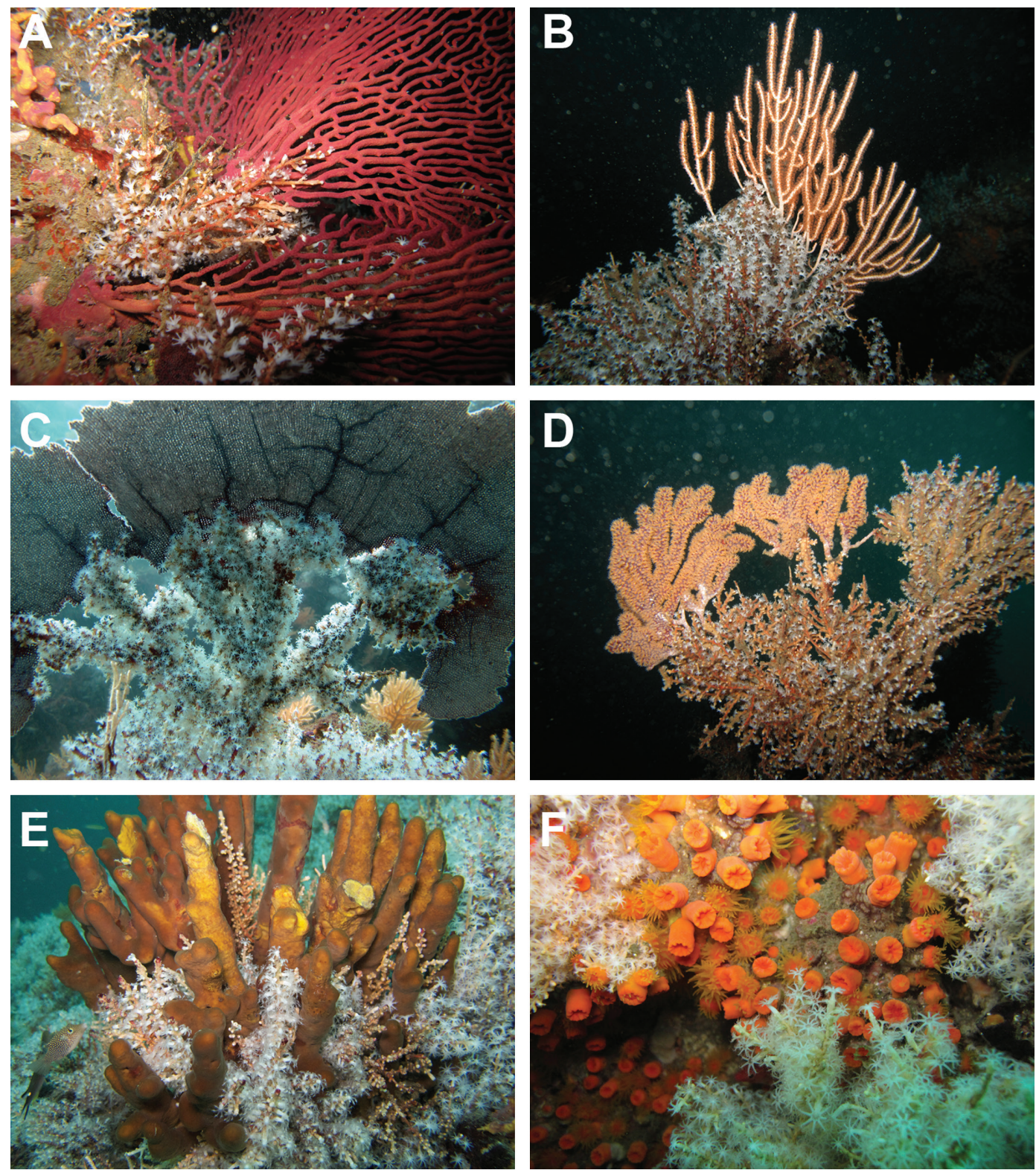

Fig. 1. Aggressive overgrowth of Carijoa riisei on endemic Tropical Eastern Pacific octocorals and other invertebrates, Cabo Corrientes, Chocó (Colombia). A. Pacifigorgia stenobrochis, B. Leptogorgia alba, C. P. irene, D. Muricea crassa, E. Aplysina chiriquiensis (sponge), F. Tubastraea coccinea (aposymbiotic scleractinian coral).

The newest large $C$. riisei mat was observed during 2011 in El Horno $(\sim 12-15 \mathrm{~m})$ along the rocky wall of this rocky feature. A number of Leptogorgia alba colonies were affected at the edge of the growing mat; the mat and tagged colonies were not observed in 2013 but $C$. riisei remained in deeper areas nearby. During 2011 at two sites, Laberinto and Montañita 2, 52 and 25 colonies respectively were tagged in 2011 , but only seven colonies in Laberinto (13\%) and one in Montañita (4\%) were found alive in 2013, all other tags were found either still 

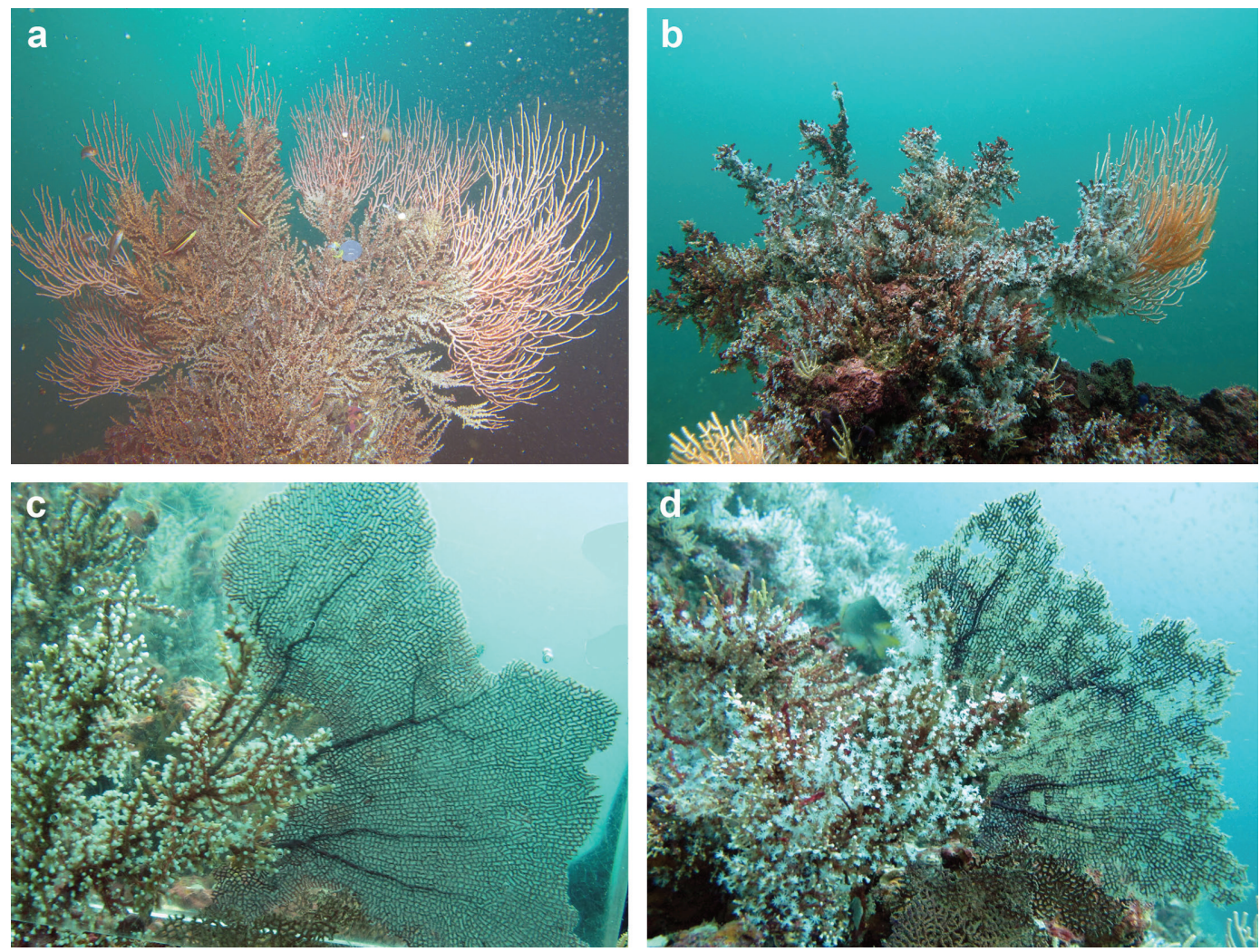

Fig. 2. Gorgonian corals attacked by Carijoa riisei in Cabo Corrientes, Chocó, Colombia (12 m). (A-B): Same colony of Leptogorgia alba during March 2010 and April 2011 respectively. (C-B): Same colony of Pacifigorgia irene during December 2011 and April 2012 respectively.
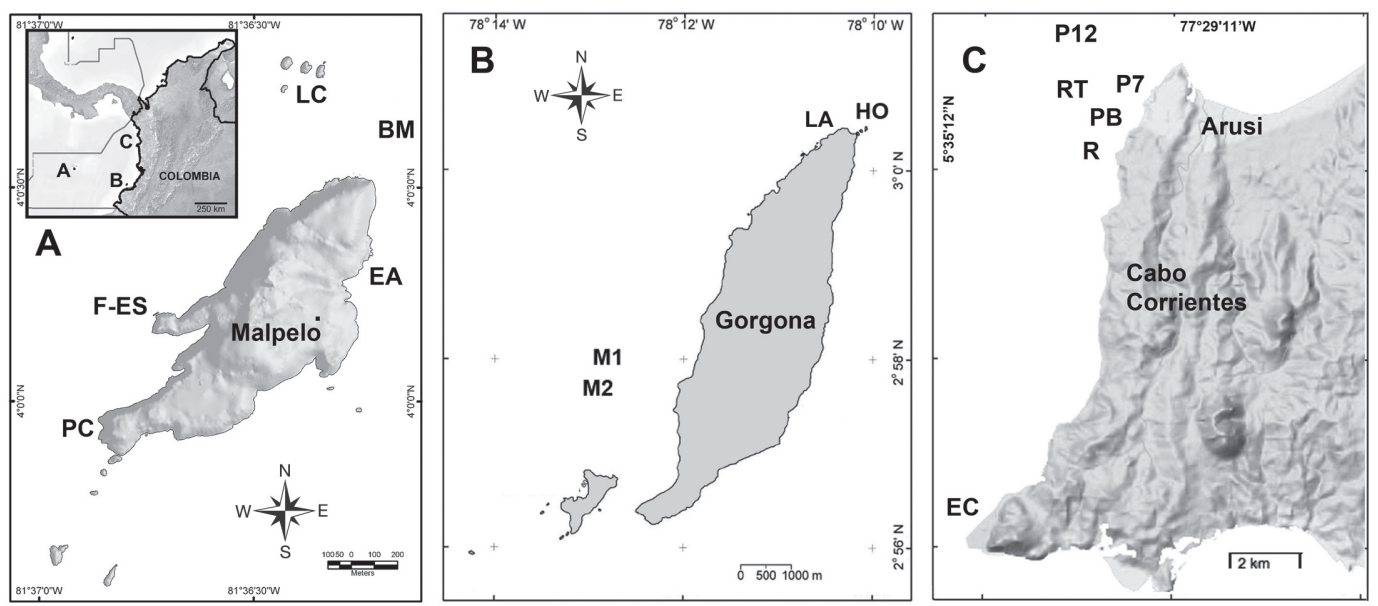

Fig. 3. Map showing old and recent appearances of large Carijoa riisei-dominated areas in several sites at the Tropical Eastern Pacific (Colombia) since 2007. A. Malpelo Island (BM: Bajo el Monstruo; EA: El Arrecife; F-ES: El FreezerEl Submarino; LC: La Catedral; PC: La Puerta del Cielo), B. Gorgona Island (M1: Montañita 1; M2: Montañita 2; LA: Laberinto; HO: El Horno), C. Cabo Corrientes, Chocó (EC: EL Cabo; PB: Piedra Bonita; P7: Parguera 7; P12: Parguera 12; R: Roñosa; RT: Rocata). 

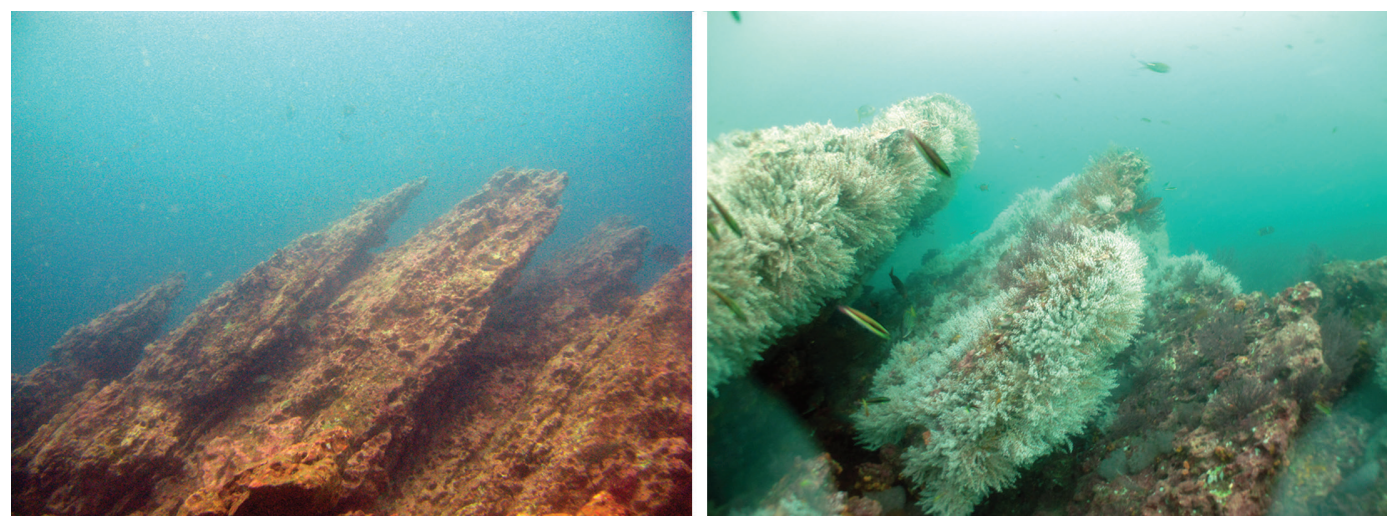

Fig. 4. Rocky outcrops in "La Montañita 2" reef at Gorgona island (12m), Tropical Eastern Pacific, Colombia, during November 2009 (left) and May 2010 (right).

attached on dead gorgonian skeletons $(20 \%$ Laberinto, none in Montañita 2) or were missing $(67 \%$ and $96 \%$ respectively). In summary, the mortality of gorgonian corals due to $C$. riisei interaction and/or overgrowth was over $87 \%$, after two years.

Malpelo Island: $C$. riisei has been observed in the rocky keys of La Catedral for over 15 years (S. Bessudo, personal communication). This site has a cavern that goes through the rock from the surface down to $25 \mathrm{~m}$ of depth and extends for about $20 \mathrm{~m}$. The walls sustain dense stands of $C$. riisei. However, at the entrance and exit of the underwater cavern, the invasive octocoral colonized the exterior walls of the rock and during 2011 a few colonies Pacifigorgia cairnsi were observed overgrown by $C$. riisei. The site with the largest mat of $C$. riisei faces El Freezer along the parallel rock promontory named El Submarino, which resembles a surfacing military submarine. The wall in this dark passage sustains a dense $P$. cairnsi community visibly affected by $C$. riise $i$ between 8 to $15 \mathrm{~m}$. Smaller colonies of $C$. riisei have been detected since 2009 in El Monstruo (30m), La Puerta del Cielo cavern $(15 \mathrm{~m})$ and more recently (2012) near El Arrecife (12m). Observations during July 2013 at El Submarino and La Catedral rendered the same $C$. riise $i$ situation like previous years.
Cabo Corrientes. $C$. riisei has been observed relatively recently in the area, probably within the last five years (A. Gómez, personal communication). All sites colonized by $C$. riisei have very similar characteristics with huge castle-like rocky promontories reaching as shallow as $6-8 \mathrm{~m}$ in depth, where the shallowest areas had the highest $C$. riisei cover. We witnessed how one of the sites, Piedra Bonita, did not have visible colonies of $C$. riisei during 2008 and was completely colonized above $10 \mathrm{~m}$ by 2010 , which included the demise of a diverse Muricea spp. community (unpublished data). Figs. 1 and 2 show how $C$. riisei can overgrow and kill large octocoral colonies in less than a year in this region. Most Pacifigorgia irene colonies that were already overgrown by $C$. riisei in July 2010 receded the following months, but had a steady positive growth rate from December 2010 and averaging roughly $1 \mathrm{~cm}$ per month whereas killing the affected octocoral proportionally (Fig. 5). Three of the monitored colonies died as a consequence of C. riisei overgrowth. In Rocata, we observed schools of Cortez angelfish, Holocanthus passer, feeding heavily on $C$. riisei but those $C$. riisei populations looked as healthy and abundant as places without the fish. We also observed in several locations during 2010, large amounts of $C$. riisei loose on the bottom as a product 


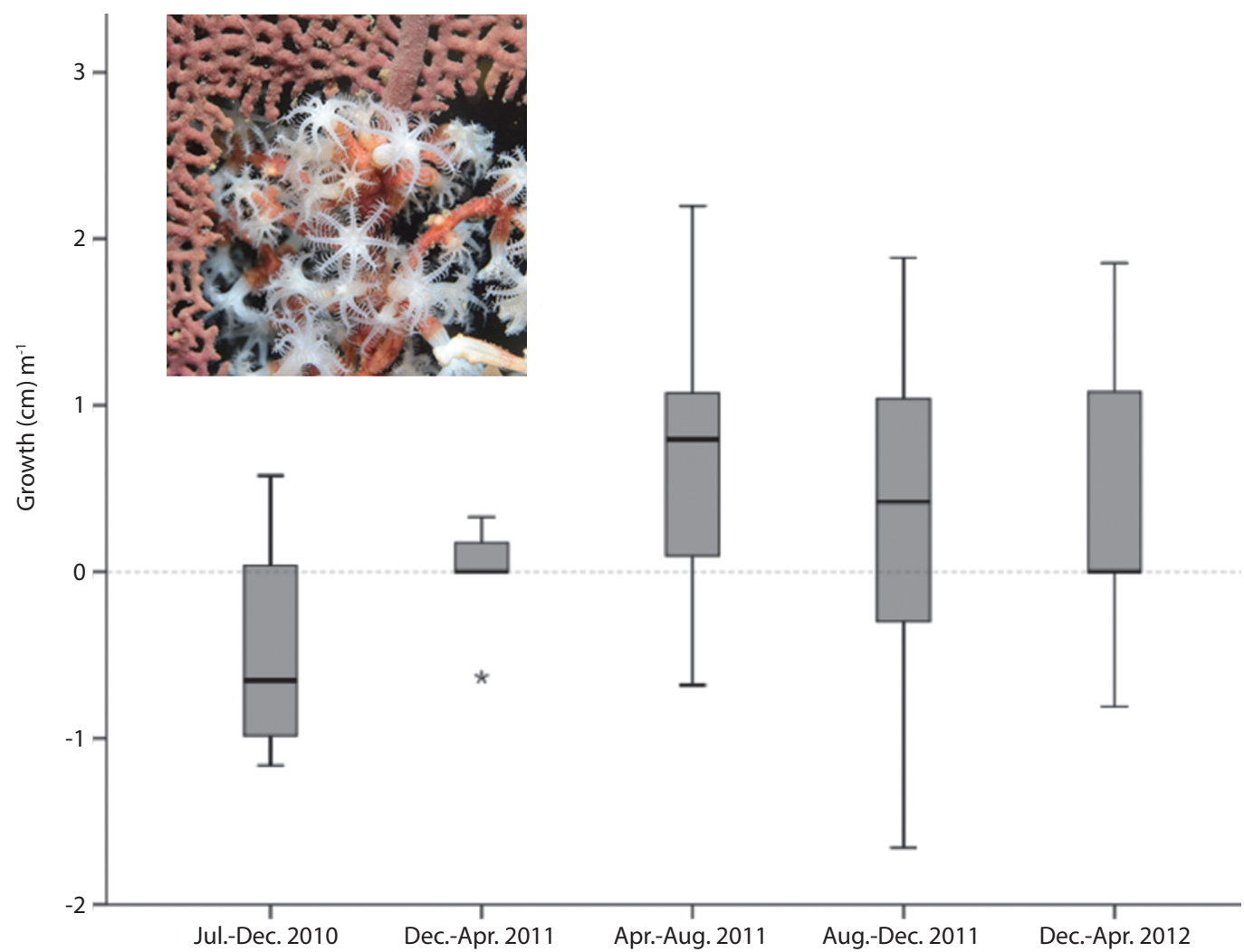

Fig. 5. Box plots (median and quartiles) of monthly lineal growth rates $\left(\mathrm{cm} \mathrm{m}^{-1}\right)$ of 15 colonies of Carijoa riisei actively overgrowing sea fan colonies of Pacifigorgia irene between July 2010 and April 2012 in Cabo Corrientes (10-15m), Chocó, Colombia.

of mass dislodgement over large areas for unknown reasons.

\section{DISCUSSION}

Despite the preliminary, and mostly qualitative, nature of our observations, it is clear that C. riisei poses a threat to the native octocoral fauna in oceanic and coastal rocky reefs of the TEP. We observed octocoral community-wide mortalities and a lasting occurrence of $C$. riise $i$ competing and overgrowing Pacifigorgia sea fans and Leptogorgia sea whips at multiple TEP sites between 2009 and 2013. The presence of $C$. riseii in the TEP is a great conservation concern because it threatens a number of endemic gorgonian corals (35 potential Pacifigorgia species for instance) in an area where over $10 \%$ invertebrates have high extinction risk (Polidoro et al., 2012). The threat of local extinction due to $C$. riisei to shallow water $(<10 \mathrm{~m})$ TEP octocorals is evident given its capacity to overgrowth and to kill other octocorals at a constant rate. This is the case of Muricea spp., which are threatened by the overgrowth of the invasive species in these habitats. It has been argued that the impacts of invasive species on native marine fauna differ from those of terrestrial or freshwater environments, because they are moderate, temporary and do not lead to species extinction (Briggs, 2010), what is known as the accommodation hypothesis. It is possible that pelagic species do not compete as closely as benthic species, so this hypothesis may not hold in the case of gorgonian corals and $C$. riisei, but it has never been tested. 
Besides the long and documented case of C. riisei invasion in Hawaii, there have also been recent population explosions of snowflake coral in the Indopacific and Indian oceans. $C$. riisei has been spotted within the last ten years in Indonesia (Calcinai et al., 2004) and in the last few years in the Indian Ocean (Padmakumar, Chandran, Kumar, Yogesh \& Sornaraj, 2011, Dhihya, Sachithanandam \& Mohan, 2012). It is unclear if all the population explosions belong to the same species or to a complex of cryptic species (Concepcion et al., 2010), but all cases involve fast colonization of benthic habitats and overgrowing some native species. Another alternative for these new records of $C$. riisei is a population strategy relying on periodic range shifts (Sexton, McIntyre, Angert \& Rice, 2009), whose geographic changes could take several decades to occur. If this were the case, $C$. riisei would be a "natural" disturbance that would eventually leave these areas in the TEP. Unfortunately, this is one of the less studied areas in the ocean and there are no ecological studies of these rocky reefs or octocoral populations before 2000, which keep us for having a firm baseline to support a species range shift hypothesis.

Despite our short period of observation, we were able to notice great changes in C. riisei's local abundance ranging from months to years. Particularly in Gorgona Island, large and dense C. riisei occurrences completely disappear in the same time period as large new areas were colonized. A likely explanation could be that this is a highly clonal species, where older ramets eventually show senescence. C. riisei is a stoloniferous soft coral, without any rigid skeleton and very fragile branches, which are very prone to break. What is probably the key to vegetative propagation, and invasion success, may impose a constraint to withstand currents, predation or any other physical contact. In addition, we have observed how older branches get darker due to numerous epibionts. This could be the explanation for the die-off of large colony mats. In contrast, we saw one of the healthiest $C$. riisei ramets in portions of the reef that were observed grazed by Holacanthus passer, which could promote ramet renewal and regeneration in this species.

The presence of $C$. riisei in rocky reefs is not the only stressful condition along the Colombian TEP. Our observations coincide with several thermal anomalies in the area leading to octocoral fungal diseases and mass mortalities (Sánchez et al., 2011, BarreroCanosa et al., 2013). Rising seawater temperatures, particularly during the upwelling season in the area, are related to sea fan mortalities in Malpelo and Gorgona islands (Sánchez, Ardila, Andrade, Dueñas, Navas \& Ballesteros, 2014). The synergy between $C$. riisei and changing conditions can accelerate octocoral death and likely fungal diseases (e.g., Fig. 2 C-B). On the other hand, there is resistance to succumb entirely to $C$. riisei overgrowth, which was noticeable in $13 P$. irene colonies along a 20 -month period. Likewise, the scleractinian coral $T$. coccinea usually exhibits a halo between its own tissue and the $C$. riisei mat (Fig. $1 F)$, which could mean that it involves some kind of extracoelenteric digestion against the invasive species. Adaptation or acclimation to fight $C$. riisei overgrowth is possibly ongoing in affected populations.

Finally, we should recognize that we found more questions than answers in our preliminary observations, which parallels the frustration that many other researches encounter when studying invasive species. Despite that improvised methods were used, we can conclude that $C$. riisei competes directly with native octocorals highly compromising their fitness. Local extinction of several octocorals, numerous Muricea sea candelabra and a few Pacifigorgia seafans, has occurred in many rocky reefs. The observed aggressive overgrowth of this species in TEP deserves more attention and regular monitoring programs. It is very difficult to manage an invasive species that spreads clonally by fragmentation, where manual eradication could lead to further spread. We recommend studying the senescence and regeneration processes, as well as the interaction between T. coccinea and C. riisei, as potential tools to manage this species. 


\section{ACKNOWLEDGMENTS}

This study was funded by Universidad de los Andes, Colombia (Interfacultades, Vicerrectoria de Investigaciones, and Facultad de Ciencias), National Geographic Society-Waitt grants and COLCIENCIAS (grant No. 1204521-29002). We acknowledge expeditions (2007 and 2009) to Gorgona Island organized by the PNN-Gorgona (Nancy Murillo, Ximena Zorrilla, Luis Payan, Héctor Chirimia Gonzalez, Eduardo Sandoval, and all the park staff) and Fundación Yubarta (Lilian Florez) and several expeditions 2009-2012 to SFF Malpelo island organized and supported by Fundación Malpelo (Sandra Bessudo, Germán Soler, Stan Teillaud, Miguel Angel Ruíz and Adriana Guzmán). We appreciate the help from colleagues and students from BIOMMAR for assistant in the field and laboratory Nestor Ardila, Luisa Dueñas, Catalina Ramírez, Elena Quintanilla, Fabio Casas, Adriana Sarmiento, Natalia Jimenez and Stefania Gutierrez, and Universidad del Valle (Fernando Zapata and Catherine Sánchez). We recognize the participation and support from local communities. Sven Zea kindly identified TEP sponges from photographs. We recognize the participation and support from local communities.

\section{RESUMEN}

Carijoa riisei (Octocorallia: Cnidaria), una especie nativa del Atlántico Occidental. Sin embargo, se ha reportado como especie exótica invasora en el Pacífico desde hace unos cuarenta años y en la costa occidental de Colombia hace 15-20 años. Recientemente $C$. riisei se ha observado sobrecreciendo octocorales nativos en varios litorales rocosos coralinos en el Pacífico Oriental Tropical-(POT) de Colombia. C. riisei ha habitado estos arrecifes durante al menos 15 años, pero este comportamiento agresivo frente a otros octocorales no se habían notado hasta hace unos pocos años. En este estudio, se evalúa por primera vez, en las zonas costeras y oceánicas, la distribución e incidencia C. riisei en otros octocorales del POT colombiano (Malpelo, Gorgona y Cabo Corrientes), incluyendo información observaciones entre 2007-2013. Hemos observado mortalidad en toda la comunidad de octocorales (incluyendo la extinción local de algunas especies de Muricea) y una constante competencia y cubrimiento de abanicos de mar Pacifigorgia y gorgonáceos Leptogorgia. C. riisei presento una tasa lineal de crecimiento sobre otros octocorales de aproximadamente $1 \mathrm{~cm} \mathrm{~m}^{-1}$. El comportamiento agresivo de $C$. riisei en el POT merece más atención y programas regulares de monitoreo.

Palabras clave: Carijoa riisei, octocorales, especies invasoras, Pacífico Oriental Tropical, Gorgona, Malpelo, Cabo Corrientes, Chocó, Colombia.

\section{REFERENCES}

Barrero-Canosa, J., Dueñas, L. F. \& Sánchez, J. A. (2013). Isolation of Potential Fungal Pathogens in gorgonian corals at the Tropical Eastern Pacific. Coral Reefs, 32: $35-41$.

Bayer, F. M. (1961). The shallow water Octocorallia of the West Indian region, Martinus Nijoff. The Hague, Netherlands.

Briggs, J. (2010). Marine biology: the role of accommodation in shaping marine biodiversity. Marine Biology, 157: 2117-2126.

Cadena, N. J. \& Sánchez, J. A. (2010). Colony growth in the harvested octocoral Pseudopterogorgia acerosa in a Caribbean coral reef. Marine Ecology Progress Series, 31: 566-573.

Calcinai, B., Bavestrello, G. \& Cerrano, C. (2004). Dispersal and association of two alien species in the Indonesian coral reefs: the octocoral Carijoa riisei and the demosponge Desmapsamma anchorata. Journal of the Marine Biological Association of the United Kingdom, 84: 937-941.

Concepcion, G. T., Kahng, S. E., Crepeau, M. W., Franklin, E. C., Coles, S. L. \& Toonen, R. J. (2010). Resolving natural ranges and marine invasions in a globally distributed octocoral (genus Carijoa). Marine Ecology Progress Series, 401: 113-127.

Dhihya, P., Sachithanandam, V. \& Mohan, P. M. (2012). New record of Carijoa riisei at Wandoor-Mahatma Gandhi Marine National Park [MGMNP], Adaman adn Nicobar Islands, India. Indian Journal of GeoMarine Sciences, 41: 212-214.

Gutiérrez, A. S. (2010). Evaluación del impacto de una especie de octocoral invasora (Carijoa riisei) en el Pacífico Oriental Tropical. Universidad de los Andes, Bogotá, Colombia.

Gútierrez, S. (2012). El invasor del Pacífico. Hipótesis, 12: 6-7.

Kahng, S. E. \& Grigg, R. (2005). Impact of an alien octocoral, Carijoa riisei, on black corals in Hawaii. Coral Reefs, 24: 556-562.

Kahng, S. (2006). Ecology and ecological impact of an alien octocoral (Carijoa riisei) in Hawai'i, United States (Doctoral dissertation). University of Hawai'i at Manoa, Honolulu, Hawaii. 
Kahng, S. E., Benayahu, Y., Wagner, D. \& Rothe, N. (2008). Sexual reproduction in the invasive octocoral Carijoa riisei in Hawaii. Bulletin of Marine Science, 82: 1-17.

Lasker, H. R., Boller, M. L., Castanaro, J. \& Sanchez, J. A. (2003). Determinate growth and modularity in a gorgonian octocoral. The Biological Bulletin, 205: 319-330.

Padmakumar, K., Chandran, R., Kumar, J. S., Yogesh, \& Sornaraj, R. (2011). Carijoa riisei (Cnidaria : Octocorallia : Clavulariidae), a newly observed threat to Gulf of Mannar coral biodiversity? Current Science, 100: 35-37.

Polidoro, B. A., Brooks, T., Carpenter, K. E., Edgar, G. J., Henderson, S., Sanciangco, J. \& Robertson, D. R. (2012). Patterns of extinction risk and threat for marine vertebrates and habitat-forming species in the Tropical Eastern Pacific. Marine Ecology Progress Series, 448: 93-104.

Sánchez, J. A. (1994). Presencia de Stylatula diadema Bayer (Pennatulacea) y Carijoa riisei (Duchassaing \& Michelotti) (Telestacea) en el Caribe suroccidental,
Colombia. Anales del Instituto de Investigaciones Marinas de Punta de Betín, 23: 137-147.

Sánchez, J. A., Gómez, C. E., Escobar, D. \& Dueñas, L. F. (2011). Diversidad, abundancia y amenazas de los octocorales de la isla Malpelo, Pacífico Oriental Tropical, Colombia. Boletín de Investigaciones Marinas y Costeras, 40: 139-154.

Sánchez, J. A., Ardila, N. E., Andrade, Dueñas, L., Navas, R. \& Ballesteros, D. (2014). Octocoral densities and mortalities in Gorgona Island, Colombia, Tropical Eastern Pacific. Revista de Biología Tropical, Vol. 62 (Supp. 1): 209-219.

Sexton, J. P., McIntyre, P. J., Angert, A. L. \& Rice, K. J. (2009). Evolution and Ecology of Species Range Limits. Annual Review of Ecology, Evolution and Systematics, 40: 415-436.

Wagner, D., Kahng, S. E. \& Toonen, R. J. (2009). Observations on the life history and feeding ecology of a specialized nudibranch predator (Phyllodesmium poindimiei), with implications for biocontrol of an invasive octocoral (Carijoa riisei) in Hawaii. Journal of Experimental Marine Biology and Ecology, 372: 64-74. 
